\title{
South American rattlesnake bite and soft-tissue infection: report of a case
}

\author{
Acidente crotálico e infecção de partes moles: relato de um caso
}

\section{Sérgio de A. Nishioka, Miguel T. Jorge, Paulo Vitor P. Silveira and Lindioneza A. Ribeiro}

\begin{abstract}
The case of a man bitten by a South American rattlesnake (Crotalus durissus) and who developed an abscess at the site of the bite is reported. Abcesses are a rare complication of this type of envenoming, possibly due to the lack of a strong cytotoxic action of Crotalus durissus venom.
\end{abstract}

Key-words: Crotalus durissus. Rattlesnake. Snake bite. Soft-tissue infection.

Resumo Relata-se o caso de um acidente ofídico por Crotalus durissus que apresentou como complicação abscesso no local da picada. Abscessos são uma complicação rara deste tipo de acidente, possivelmente porque o veneno de serpentes da espécie Crotalus durissus não apresenta uma forte ação citotóxica.

Palavras-chaves: Cascavel. Crotalus durissus. Infecção de partes moles. Picada de cobra.

Abscesses are a complication of rattlesnake bite in the United States, but have not been reported in South America, where rattlesnakes are represented by a different species, Crotalus durissus. Envenoming by South American rattlesnakes result in systemic but not severe local envenoming ${ }^{4}{ }^{7}$. We report here a case of soft-tissue infection following a South American rattlesnake bite and comment on the rarity of this finding.

\section{CASE REPORT}

A 38-year-old man was bitten on his left foot by an $86 \mathrm{~cm}$ wild rattlesnake, later identified as Crotalus durissus collilineatus. He did not use a tourniquet nor interfere with the bite wound in anyway, nor did he receive local treatment before arriving at the hospital, where he was given 12 ampoules of Crotalus antivenom (Butantan Institute, São Paulo, Brazil) which were administered intravenously seven hours after the bite. He had the classical manifestations of South American rattlesnake envenoming ${ }^{4}$, including severe myalgia, dark urine, palpebral ptosis, and ophthalmoplegia; however, he did not develop renal failure, and was discharged virtually asymptomatic after 5 days. During his stay in hospital the patient had no evidence of an inflammatory process at the site of the bite, but he did complain of local pain during the first day, and of local numbness which persisted until the day of his discharge. The patient returned a week later for a follow-up visit, complaining that in the previous days he had noted pain, swelling and redness at the site of the bite and that, later, a blister appeared there. He denied having used

Centro de Ciências Biomédicas da Universidade Federal de Uberlândia, Uberlândia, Brazil.

Financial support was obtained from the European Community, Contract IC18-CT96-0032.

MTJ is a researcher supported by the Brazilian Research Council (CNPq).

Address to: Dr. Sérgio de A. Nishioka. Al. Sosthenes Guimarães 667, 38411-160 Uberlândia, MG, Brazil.

Tel: 5534218 2246; fax: 55342182349 or 55342328620

e-mail: snishioka@triang.com.br

Recebido em 13/10/99. 
any drug, locally or systemically, and he had no fever during this period. Examination of his left foot revealed the presence of a blister below his left ankle, with no inflammatory signs.

The blister was aspirated, and its content was sent for microbiological study. Culture of this fluid for aerobic bacteria was positive for Escherichia coli and Staphylococcus aureus. The former was sensitive in vitro to ampicillin, aminoglycosides, fluoroquinolones, first, second and third generation cephalosporins, carbapenems, aztreonam and piperacillin-tazobactam, and was resistant only to trimethoprim-sulfamethoxazole. The strain of $S$. aureus was resistant to tetracycline and clindamycin, and sensitive to oxacillin, erythromycin, trimethoprimsulfamethoxazole, rifampicin, aminoglycosides, first, second and third generation cephalosporins, glycopeptides, fluoroquinolones, carbapenems and piperacillin-tazobactam. The patient did not receive antimicrobial therapy and recovery was uneventful.

\section{DISCUSSION}

In South America soft-tissue infection is a wellknown complication of patients bitten by lanceheaded vipers (genus Bothrops), whose venom has strong cytotoxic action which may favour the growth in the injured tissue of bacteria inoculated from the venom and fangs of the snakes. Enterobacteria such as Morganella morganii and Escherichia coli, and anaerobes have in the past been the most commonly species isolated from abscesses complicating Bothrops bites, whereas Gram positive cocci such as Staphylococcus aureus are apparently of less importance ${ }^{56}$. Anaerobes and Gram negative rods have also been isolated from the venom, fangs, fang sheaths and saliva of wild and captive lance-headed vipers ${ }^{3}$, South American and North American rattlesnakes ${ }^{12}$, and from other snakes from outside the American continent ${ }^{8}$.
Soft-tissue infection can be an important complication of snake bite with local envenoming. This effect rarely occurs in bites by South American rattlesnakes, although its occurrence may have been underestimated because of insufficient follow-up, or underreported because the cases are mild and self-limited as described here. Given that bacteria are commonly found in the venom and mouth cavities of several genera of snakes, the lack of strong cytotoxic action of the venom of South American rattlesnakes is probably the most likely explanation for the rarity of local infections following their bites. The prophylactic use of antibiotics following South American rattlesnake bite should not be recommended.

\section{REFERENCES}

1. Garcia-Lima E, Laure CJ. A study of bacterial contamination of rattlesnake venom. Revista da Sociedade Brasileira de Medicina Tropical 20:19-21, 1987.

2. Goldstein EJC, Citron DM, Gonzalez H, Russell FE, Finegold SM. Bacteriology of rattlesnake venom and implications for therapy. Journal of Infectious Diseases 140:818-821, 1979.

3. Jorge MT, Mendonça JS, Ribeiro LA, Silva MLR, Kusano EJU, Cordeiro CLS. Flora bacteriana da cavidade oral, presa e veneno de Bothrops jararaca: possível fonte de infecção no local da picada. Revista do Instituto de Medicina Tropical de São Paulo 32:6-10, 1990.

4. Jorge MT, Ribeiro LA. Epidemiologia e quadro clínico do acidente por cascavel sul-americana (Crotalus durissus). Revista do Instituto de Medicina Tropical de São Paulo 34:347-354, 1992.

5. Jorge MT, Ribeiro LA, Silva MLR, Kusano EJU, Mendonça JS. Microbiological studies of abscesses complicating Bothrops snakebite in humans: a prospective study. Toxicon 32:743-748, 1994.

6. Nishioka SA, Silveira PVP. Bacteriology of abscesses complicating bites of lance-headed vipers. Annals of Tropical Medicine and Parasitology 76:89-91, 1992.

7. Silveira PVP, Nishioka SA. South American rattlesnake bite in a Brazilian teaching hospital: clinical and epidemiological study of 87 cases, with analysis of factors predictive of renal failure. Transactions of the Royal Society of Tropical Medicine and Hygiene 86:562-564, 1992.

8. Theakston RDG, Phillips RE, Looareesuwan S, Echeverria P, Makin T, Warrell DA. Bacteriological studies of the venom and mouth cavities of wild Malayan pit vipers. Transactions of the Royal Society of Tropical Medicine and Hygiene 84:875-879, 1990. 